University of Nebraska - Lincoln

DigitalCommons@University of Nebraska - Lincoln

$4-15-2004$

\title{
Highly Selective, Electrically Conductive Monolayer of Nanoparticles on Live Bacteria
}

\author{
V Berry \\ Virginia Polytechnic Institute and State University \\ RangaSwamy S \\ Virginia Polytechnic Institute and State University \\ Ravi F. Saraf \\ University of Nebraska-Lincoln, rsaraf2@unl.edu
}

Follow this and additional works at: https://digitalcommons.unl.edu/chemeng_nanotechnology

Part of the Nanoscience and Nanotechnology Commons

Berry, V; S, RangaSwamy; and Saraf, Ravi F., "Highly Selective, Electrically Conductive Monolayer of Nanoparticles on Live Bacteria" (2004). Papers in Nanotechnology. 6.

https://digitalcommons.unl.edu/chemeng_nanotechnology/6

This Article is brought to you for free and open access by the Chemical and Biomolecular Engineering Research and Publications at DigitalCommons@University of Nebraska - Lincoln. It has been accepted for inclusion in Papers in Nanotechnology by an authorized administrator of DigitalCommons@University of Nebraska - Lincoln. 
(C) 2004 American Chemical Society.

The American Chemical Society allows the posting of only the title, abstract, tables, and figures from articles appearing in the Nano Letters.

This article is published on web 04/15/2004 Nano Lett., Vol. 4, No. 5, 2004 (939-942)

10.1021/nI0495716 ㄷ 2004 American Chemical Society

http://dx.doi.org/10.1021/n10495716

\title{
Highly Selective, Electrically Conductive Monolayer of Nanoparticles on Live Bacteria
}

\author{
V. Berry, S. Rangaswamy, and R. F. Saraf * \\ Received March 18, 2004; Revised Manuscript Received March 30, 2004
}

\begin{abstract}
Using specific peptide bacteria affinity, a monolayer of $30 \mathrm{~nm}$ Au particle is selectively deposited on live bacteria surface to produce electrically conducting bridges spanning over $12 \mu \mathrm{m}$. The conductivity of the monolayer network is further improved by over 10-fold by "electric-field annealing". The annealing process is explained by a percolation model.
\end{abstract}



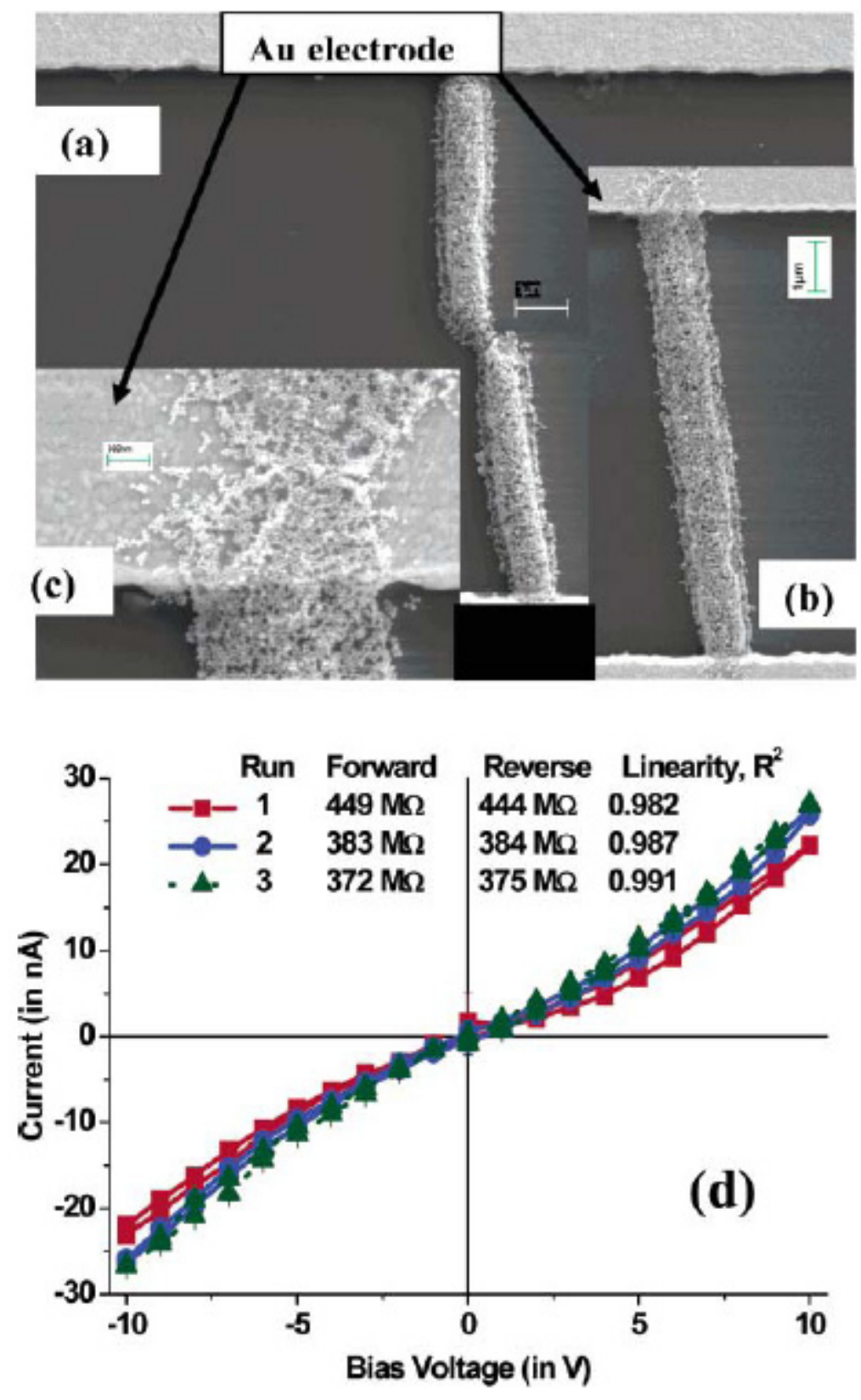

Figure 1. (a), (b) Typical FESEM images showing bacteria coated with $\mathrm{Au}$ nanoparticle monolayers and spanning between two $\mathrm{Au}$ electrodes at the extreme ends. The size bar is $1 \mu \mathrm{m}$. (c) The nanoparticle size and monolayer morphology are more evident at higher magnification. The size marker is $300 \mathrm{~nm}$. (d) Typical $I-V$ characteristics of as-received (run \#1) and subsequent cycles of a device with 15 bridges between the electrodes. The error bars on each data point are based on 10 points over a time period of $5 \mathrm{~s}$. The resistance is measured by fitting a line through the origin with fitness parameter $R^{2}$. The $I-V$ characteristics become reproducible after the first run. 


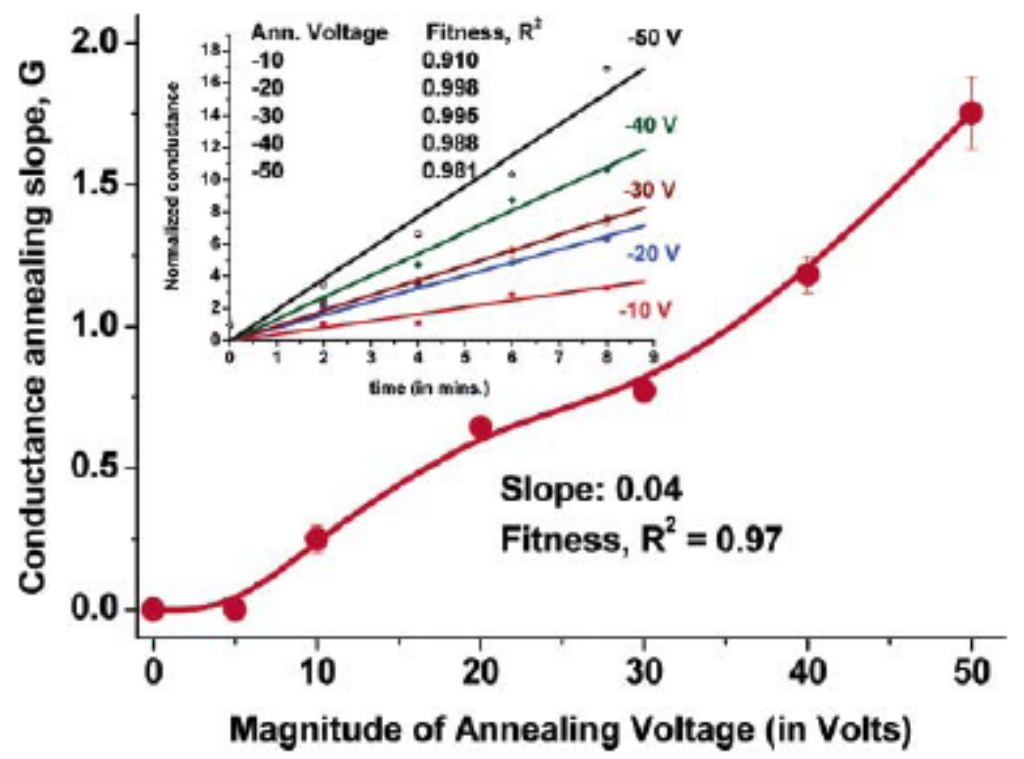

Figure 2. Normalized conductance is defined as $R_{i} / R$, where $R_{i}$ is the resistance at $t=0$ (i.e., after the third cycle in Figure 1). All the devices are on the same chip and therefore fabricated under identical conditions. The slope $G$ is in $\mathrm{min}^{-1}$. 


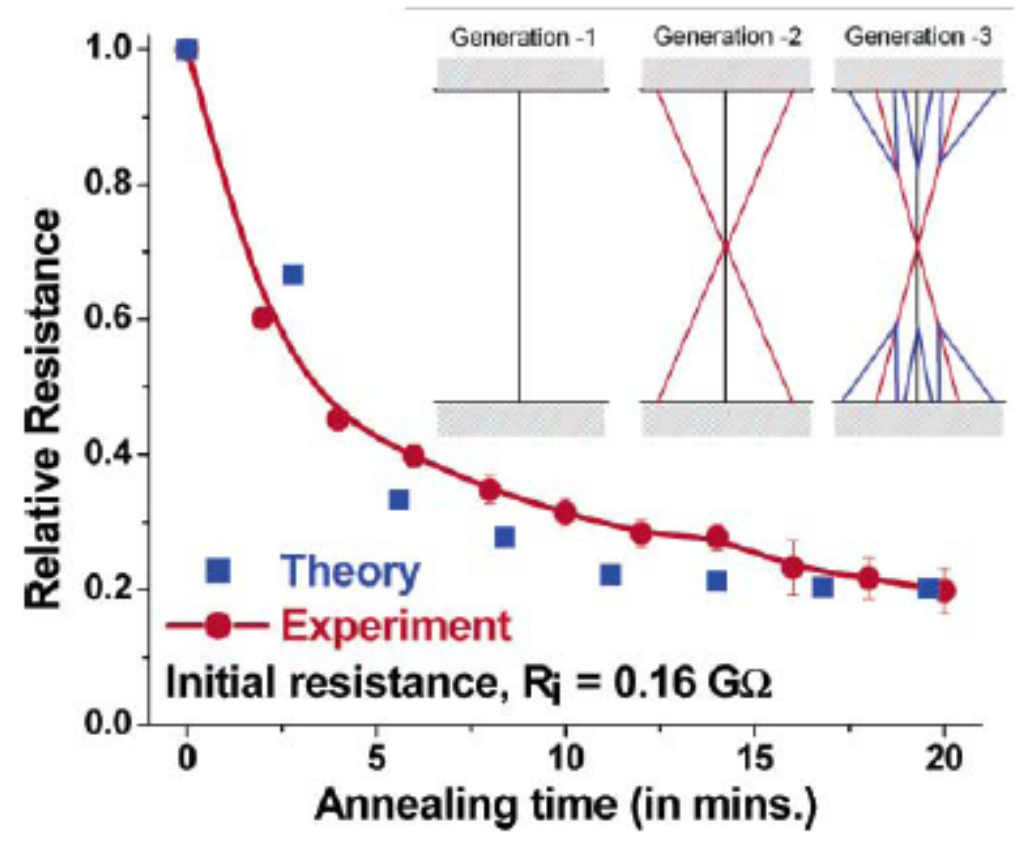

Figure 3. Annealing time versus relative resistance, $R / R_{i}$ of a sample showing the plateau region after $\sim 20 \mathrm{~min}$. The theory points are based on the percolation model for coordination number, $f+1$ $=4$. Inset shows three generations due to $f=3$ branching. The channels are drawn as straight lines for simplicity. 